\title{
Karl Marx's thoughts on functional income distribution: a critical analysis from a Keynesian and Kaleckian perspective
}

\author{
Hansjörg Herr* \\ Berlin School of Economics and Law and Berlin Institute for International Political Economy (IPE), \\ Germany, and FMM Fellow
}

\begin{abstract}
In Marx's explanation of functional income distribution, wages are given as a basket of goods needed for the reproduction needs of the working class. Profits are then the remaining part of income creation. Marx's explanation of functional income distribution has several theoretical and practical shortcomings. The Keynesian paradigm in the traditional works of Keynes and Kalecki provides alternative explanations of functional income distribution. Here the profit rate is given by processes in the financial market and the degree of financialisation. Also the degree of monopoly influences functional income distribution. The Keynesian and Kaleckian approach allows a plausible interpretation of the changes in functional income distribution during recent decades.
\end{abstract}

Keywords: Marxism, functional income distribution, John Maynard Keynes, Michat Kalecki

JEL codes: $B 510, B 31, E 25$

\section{INTRODUCTION}

Since Thomas Piketty (2014) published his Capital in the Twenty-First Century, inequality has become a key topic in political and theoretical debates. There is consensus that inequality in income and wealth distribution has been increasing substantially during recent decades in developed as well as developing countries. At the centre of the discussion in this paper is functional income distribution, referring to the division of income into labour income and non-labour income. Here, the latter is called profit and consists of interest, dividends, undistributed profits, and other non-labour income. Of course, the wage share (wages to income) and the profit share (profits to income) add up to one. The profit share in most countries in the world during recent decades has increased, adding substantially to increasing inequality of personal income distribution.

How can income distribution and its changes be explained? Different economic paradigms give different answers. Karl Marx was one of the economists who pointed out that exploitation, which leads to inequality, is one of the characteristics of capitalist systems. It is fruitful to compare Marx's approach with other economic approaches. Especially interesting in this context is the comparison with John Maynard Keynes, as he also presents a model in which capital is able to appropriate income in spite of his argument that all

* Berlin School of Economics and Law, Badensche Str. 52, 10825 Berlin, Germany; email: hansherr@hwr-berlin.de. For many helpful comments and debates I thank Eckhard Hein.

Received 14 October 2018, accepted 22 January 2019 
income is created by labour. Moreover, Michał Kalecki, who made further noteworthy contributions to this debate, is worth discussing. The focus of this contribution is to clarify the basic arguments of different economic paradigms to explain functional income distribution.

In Section 2, Marx's approach to explaining functional income distribution is discussed. Section 3 sketches the neoclassical explanation of functional income distribution. Keynes's and Kalecki's contribution in the framework of a post-Keynesian paradigm are discussed in Sections 4 and 5. Section 6 gives a synthesis of the Keynesian and Kaleckian approach. An interpretation of the empirical development during recent decades is given in Section 7.

\section{FUNCTIONAL INCOME DISTRIBUTION IN MARX'S THOUGHT}

Marx (1867), in Volume I of Capital, distinguishes between labour and labour-power. His theory of exploitation is built on this difference. Labour is the activity of a person in the production of goods (here always including services). Following the classical paradigm, all values are created by labour (see Adam Smith 1776 [2007]). Value is measured by labourunits (hours, minutes, etc.). The value of intermediate and capital goods which are used in a production process is transferred to the newly produced goods. Labour-power is the potential of a worker to work. A capitalist hires a worker for a certain period of time and uses his or her labour-power. The key point for Marx is that the price of hiring a worker - or the value of labour-power, as Marx calls it - is lower than the value a worker can produce. The difference between the value created by a worker and the value of his or her labour-power is the surplus value or profit.

Given the power of the worker to create a certain value in a given period of time, the surplus value depends on the value of the labour-power. If the price of the labour-power is given, the functional distribution of income can be determined. The wage share in a country depends on the values created by the working class and the value of the labour-power of the working class. What determines the value of the labour-power?

The value of labour-power is determined, as in the case of every other commodity, by the labour time necessary for the production, and consequently also the reproduction, of this special article. ... If the owner of labour-power works to-day, to-morrow he must again be able to repeat the same process in the same conditions as regards health and strength. His means of subsistence must therefore be sufficient to maintain him in his normal state as a labouring individual. His natural wants, such as food, clothing, fuel, and housing, vary according to the climatic and other physical conditions of his country. On the other hand, the number and extent of his so-called necessary wants, as also the modes of satisfying them, are themselves the product of historical development ... . In contradistinction therefore to the case of other commodities, there enters into the determination of the value of labour-power a historical and moral element. Nevertheless, in a given country, at a given period, the average quantity of the means of subsistence necessary for the labourer is practically known. (Marx 1867: 120f)

This quote shows that Marx assumes a given basket of goods or a given real wage, which is needed for the reproduction of workers and their families and also may be the result of class struggles. Given this basket, the surplus is the remaining part of the income created. Or, in other words, a worker works part of his or her working time for himself or herself, whereas the remaining surplus labour produces the surplus or the profit. Here, Marx follows the tradition of Adam Smith and David Ricardo, who also explain functional income distribution by fixing a real wage - that is, a basket of goods - with the profit as the remaining part of income created. 
For Marx, one of the positive and main characteristics of capitalism is its power to increase productivity. The possibility of earning extra profits, ${ }^{1}$ combined with the danger to lose in the competitive struggle and go bankrupt, create powerful incentives for firms to continuously modify the production process. According to Marx (1867: part 3), the incentive to earn profits and survive in the competitive struggle include efforts such as increasing working time, making work more intensive (viewed as a negative way of increasing productivity), and innovating and using better machines to produce existing and new goods (viewed as a good way of increasing productivity). This process of creative destruction, as Joseph Schumpeter (1942 [2014]) called it, is the secret to why capitalism, in comparison to all other modes of production known to date, is so successful in increasing productivity and driving innovation. ${ }^{2}$ The process of relative value creation, as Marx called this innovation process, permanently increases productivity and reduces the value of labour-power, which in turn increases the surplus.

The object of all development of the productiveness of labour, within the limits of capitalist production, is to shorten that part of the working day, during which the workman must labour for his own benefit, and by that very shortening, to lengthen the other part of the day, during which he is at liberty to work gratis for the capitalist. (Marx 1867: 224)

Marx believed that the working class would not benefit very much from productivity increases achieved by the capitalist system. In the Communist Manifesto Marx and Engels (1848 [2006]) believed in the impoverishment of the working class. Given the extremely bad living conditions of the working class at that time this was understandable. Later Marx (1867: 121) added a historical and moral element to the definition of the physical reproduction basket of workers and did not exclude higher living standards of the masses in capitalism (Herr 2018).

For Marx, unemployment is needed to guarantee profits. Unemployment weakens the bargaining power of the working class to the extent that real wages remain relatively low and exploitation can take place. There is an endogenous mechanism in capitalism which increases unemployment when real wages become too high. A higher wage share, for Marx, is a double-edged sword: higher real wages increase the living standards of workers, but reduce profits. If profits become too low, the accumulation of capital stagnates. The resulting lower growth rate of GDP, or even recession, increases unemployment back to a level where real wages are low (Marx 1867: part 7).

There are several shortcomings associated with the approach of Marx and the classical paradigm in general:

1. Profits depend on the level of productivity. Assuming everything unchanged, higher productivity via relative value creation increases profits. If productivity becomes very low, then profits disappear. In the first basic model in Sraffa (1960) this situation is modelled as an economy without profit. There is no good theoretical argument, however, for why profits would in this way be dependent on productivity (Riese 2002). Also, empirically, in capitalist countries with very low productivity, profits exist - even when the reproduction of workers is not guaranteed.

1. Extra profits can also be called quasi-rents based on technological or other positions which allow the exploitation of a power source. In comparison to rent for land in a good location, a quasi-rent can disappear when, for example, competitors technologically catch up.

2. Unfortunately the very effective capitalist productivity machine has a defect. It does not take into account ecological problems as these do not belong to (or are only a very indirect and distorted part of) the incentive system of firms developing new technologies and goods. 
2. Marx was too pessimistic about the development of the living standard of the working class. While he mentioned that the degree of civilisation of a country plays a role in determining real wages, he assumed in the end that productivity increases would predominantly benefit capital. As mentioned, in the first half of the nineteenth century, the living conditions of the working class were very bad and the economic system was extremely unstable. However, towards the end of the nineteenth century, a more regulated type of capitalism was established. For example, the central bank got the monopoly to issue bank notes ${ }^{3}$ and started to understand better how to carry out monetary policy; the Gold Standard was established; the oligopoly of the big London-based financial institutions, the so-called 'haut finance', stabilised international capital flows and helped countries with financial problems; labour markets became more regulated (ban of child labour, regulation of working time, establishment of social security systems, stronger trade unions, etc.). The system was not as regulated as the one following World War II, but it did limit, at least until World War I, some of the regressive implications of capitalism and increased the living standard of the overwhelming majority of the population in the capitalist countries in ways that were previously unthinkable (Polanyi 1944).

3. Marx struggled with the relationship between the structure of prices and functional income distribution. Advances of capitalists can be divided into variable capital (that is, wages) and constant capital (that is, the value of intermediate goods, the means of production, such as machines or buildings, etc.). The relationship between constant and variable capital, called by Marx the organic composition of capital, differs among different industries. Marx assumes correctly that in a general model the relationship between the working time to produce the value of labour and the surplus labour (that is, the exploitation rate) is equal in all industries. Then industries with a high organic composition have a relatively low profit rate (profit to capital invested) compared to industries with a relatively low organic composition.

Owing to the different organic compositions of capitals invested in different lines of production, and, hence, owing to the circumstance that - depending on the different percentage which the variable part makes up in a total capital of a given magnitude - capitals of equal magnitude put into motion very different quantities of labour, they also appropriate very different quantities of surplus-labour or produce very different quantities of surplus-value. Accordingly, the rates of profit prevailing in the various branches of production are originally very different. (Marx 1894 [1959]: 121)

Marx continued to argue that competition between individual capitals would bring down the prices of products in industries with low organic composition and cause increases in the prices in industries with high organic composition. In this way, profits are transferred from one industry to another so that the same profit rate in all industries is realised. 'These different rates of profit are equalized by competition to a single general rate of profit, which is the average of all these different rates of profit' (Marx 1894 [1959]: 121) The problem is that, by this process, the value of constant capital must also change, as the output of one industry is the input of another. In the next round, to equalise the profit rate, this then leads again to price changes, and so on. Marx (1894 [1959]: part II), in his manuscript, struggled over many pages with this problem, but could not solve it, mainly because a system with simultaneous equations was not known to him. It was Piero Sraffa (1960) who solved the problem in an analytically clear way. According to Sraffa, given the

3. Before this, private banks were allowed to issue their own bank notes. This led to a lack of power of central banks to control and stabilise the financial system and the economy as a whole. 
technology in an economy, expressed by the input-output relationships of industries and a physical basket of goods needed for the reproduction of labour-power, then the equilibrium structure of prices, the relation between invested capital and wages for each industry, and the general rate of profit can be determined. For this consistent modelling of the classical paradigm, labour-units are not needed. There is no quantitative relationship between values, measured in labour-units, and prices. Of course, this does not invalidate the assumption that value can only be created by labour. This assumption, however, has no consequence for the prices of goods and the profit rate.

Sraffa (1960) shows one additional effect most likely not expected by Marx. Assuming the same technology in an economy, an increase of real wages, increasing for example some or all goods in the reproduction basket of labour-power, may lead to a falling or increasing profit rate. There is no clear relationship between changes of real wages and the profit rate. This fact is based on the effect that any change in the reproduction basket of workers changes the structure of prices and as a result the profit sum and the value of the stock of invested capital in an unpredicted way.

There is one last point. It is almost impossible and completely unrealistic to fix a basket of goods, which is needed for the reproduction of labour. Baskets of goods are not negotiated and determined in the labour market. If the real wage is measured in a common unit of account let us say we have a world without money and all goods needed for the reproduction of labourpower are measured in kilograms of corn - then the wage could be determined in kilograms of corn. Given the value of labour-power in kilograms of corn, the structure of prices and a general profit rate can be determined. However, "when the wage is to be regarded as "given" in terms of a more or less abstract standard' it 'does not acquire a definite meaning until the prices of commodities are determined' (Sraffa 1960: 33). This means that the basket of goods for the reproduction of labour-power is only fixed when the structure of prices is determined. There is a simple solution to this messy problem: "The rate of profits, as a ratio, has a significance which is independent of any prices, and can be "given" before the prices are fixed' (ibid.: 33) Real wages then are given as a result. Of course for classical economists such a sequence is very strange. Keynes went in this direction.

Marx and all classical economists, as well as the neoclassical economists who became dominant from the 1870 s on, ${ }^{4}$ believed that real wages are determined in the labour market. They did not take into consideration that in labour markets only nominal wages are negotiated. Keynes (1936: 13) argued that the classical and neoclassical paradigm in 'assuming that the wage bargain determines the real wage ... have slipped in an illicit assumption'. And if, for whatever reason, the working class wants to reduce the real wage level, 'there may exist no expedient by which labour as a whole can reduce its real wage to a given figure by making revised money bargains with the entrepreneurs' (ibid.: 13).

\section{THE NEOCLASSICAL MARGINAL PRODUCTIVITY THEORY OF DISTRIBUTION}

The neoclassical explanation of functional income distribution assumes that capital, land and labour as factors of production interact together in the physical production process to produce an output good. Each of the factors then receives its fair share of

4. In the 1870s William Stanley Jevons, Carl Menger and Léon Walras became the main economists establishing the neoclassical paradigm, which replaced the classical paradigm established mainly by Adam Smith and David Ricardo. 
the income created. ${ }^{5}$ John Bates Clark (1899) presented the modern version of this trinity model in the form of a macroeconomic production function which became the basis for the marginal productivity theory of income distribution. Assuming only labour and capital as production factors, firms under pure competition maximise profits when real wages are equal to the physical marginal product of labour and the rate of return on capital is equal to the physical marginal product of capital goods. In this approach, there is no exploitation of workers. Each factor of production gets its fair share of output. In this model in the labour market real wages are negotiated. As soon as trade unions realise wages above the market equilibrium level, there will be unemployment. To explain the falling wage share over recent decades, a specific technological development that privileges capital is assumed. Insufficient investment in 'human capital' also contributes to a falling wage share. For example, the OECD (2012) argues that between 1990 and 2007, around 80 per cent of the within-industry decline of wage shares stems from specific productivity developments. 'This is consistent with the idea advanced by many studies that the spread of information and communication technologies (ICTs) has created opportunities ... for unprecedented advances in innovation and inventions of new capital goods and production processes, thereby boosting productivity' (ibid.: 110).

The neoclassical model of functional income distribution relies on very specific assumptions. It only works under the assumption of smooth physical substitution between the different production factors and constant returns to scale. If the last condition is not fulfilled, the sum of distributed wages plus profits is bigger (in case of economies of scale) or smaller (in case of diseconomies of scale) than the income created in the economy. Fundamental inconsistencies of the model were revealed during the Cambridge-Cambridge debate in the 1960s. To calculate the marginal product of capital and labour, the stock of capital has to be known as well as the output produced. In comparison to labour, which can be measured in hours, capital and output in a world of heterogeneous goods have to be calculated in values. The value of a given stock of capital and the value of the output obviously depend on the structure of prices of goods. The structure of prices depends on the functional distribution of income. Here, the model is tangled up in a vicious circle: the stock of capital has to be known to determine distribution and distribution has to be known to calculate the stock of capital. Starting in equilibrium, with equal profit rates in all industries and assuming an increasing profit rate due to innovations and a higher productivity of capital, it is obvious that real wages will decrease. What is important here is that industries with relatively high capital intensity will now have a higher profit rate than industries with relatively low capital intensity. To again create an equal profit rate, the structure of prices must change. Sraffa (1960) made clear that the new equilibrium can show a lower or higher value of the capital stock, even if the physical capital stock has not changed - capital reversing is possible - and a lower or higher value of output. In addition, given a new structure of prices, firms may choose a different profit-maximising technology which may be more or less capital-intensive. Employment can increase with increasing real wages (reswitching), and interest rates may increase with an increasing capital stock even without

5. Already Marx argued strongly against such a theoretical approach. 'In capital-profit, or still better capital-interest, land-rent, labour-wages, in this economic trinity represented as the connection between the component parts of value and wealth in general and its sources, we have the complete mystification of the capitalist mode of production, the conversion of social relations into things, the direct coalescence of the material production relations with their historical and social determination. It is an enchanted, perverted, topsy-turvy world, in which Monsieur le Capital and Madame la Terre do their ghost-walking as social characters and at the same time directly as mere things. It is the great merit of classical economy to have destroyed this false appearance and illusion' (Marx 1894 [1959]: 599). 
changes in technology. Both the neoclassical demand function for labour (combining falling real wages with higher labour demand) and the demand function for capital (combining falling interest rates with increasing capital stocks) evaporates, and the neoclassical distribution model breaks down (see also Harcourt 1972; Lazzarini 2011).

Paul Samuelson (1966: 583), one of the most famous US economists after World War II, who first wanted to save the model, wrote: 'Reswitching ... does alert us to several vital possibilities. Lower interest rates ... can involve denial of diminishing returns and entail reverse capital deepening ... . There often turns out to be no unambiguous way of characterising different processes as more "capital intensive", more "mechanised", more "roundabout" ...'. To sum up: The marginal productivity theory of distribution is theoretically not defendable.

There is an interesting parallel to Marx's transformation from values to prices and the neoclassical marginal productivity model. Both fail because of difficulties to aggregate physical capital goods to a sum of value. All these problems disappear if the assumption of the existence of only one capital good is made, in other words, that the capital-towages ratio remains the same in all industries. It is an irony of economic history that Marx's transformation from labour values to prices and the neoclassical marginal productivity theory of distribution only work when one capital good (or the same capital-to-wages ratio in all industries) is assumed. However, such an assumption is not legitimate as it sidesteps a key problem in economics. Marx struggled with the problem and could not find a solution. After the 1960s for neoclassical economists it is clear that the marginal productivity theory of distribution and its consequences of capital and labour demand are not defendable, as Samuelson wrote. In the neoclassical paradigm the use of macroeconomic production functions and marginal productivities are negative heuristics in terms of Lakatos (1978) to protect the core of the paradigm with the consequence of a degeneration of the paradigm.

\section{FUNCTIONAL INCOME DISTRIBUTION IN THE KEYNESIAN TRADITION}

Keynes followed the classical paradigm (which he named pre-classical) in advocating that all values are created by labour.

I sympathise, therefore, with the pre-classical doctrine that everything is produced by labour.... It is preferable to regard labour, including, of course, the personal service of the entrepreneur and his assistants, as the sole factor of production, operating in a given environment of technique, natural resources, capital equipment and effective demand. (Keynes 1936: 214) ${ }^{6}$

Sraffa (1960: 33), following Keynes, suggests that 'the rate of profits ... is ... susceptible of being determined from outside the system of production, in particular by the level of the money rate of interest'. Interest payments are for firms a kind of cost. 'If, however, the rate of interest exceeds zero, a new element of cost is introduced which increases with the length of the process' (Keynes 1936: 216). These costs have to be covered by prices, otherwise firms go bankrupt. If a firm operates using 100 per cent borrowed money, the profit rate must be at least as high as the interest rate. If a firm uses (partly) their own capital, there are opportunity costs. Own capital will thus only be invested if it at least earns a rate of return equal to the interest rate.

6. For a comprehensive elaboration of the Post-Keynesian paradigm, see Herr (2014). 
Keynes developed a very abstract model to make his point. He assumed that, given the uncertainty in general, and especially in a capitalist system, the holding of money (or better liquidity) earns a non-pecuniary rate of return, a so-called liquidity premium. The liquidity premium falls with increasing liquidity holding, but it will not become zero and stops falling at a certain positive level. The explanation is that any additional holding of liquidity in a stable asset creates an advantage of the holder of the liquidity. The liquidity premium determines the interest rate. 'The rate of interest obviously measures ... the premium which has to be offered to induce people to hold their wealth in some form other than hoarded money' (Keynes 1937a: 216; see also Keynes 1936: ch. 17). Or 'the rate of interest on a loan of a given quality and maturity has to be established at the level which in the opinion of those who have the opportunity of choice - i.e. of wealth-holders - equalises the attractions of holding the loan' (Keynes 1937b: 250). The interest rate determines the profit rate. Keynes assumed that the rate of return of all assets that can be reproduced will fall with increasing investment until the stock of all reproducible assets reaches a rate of return equal to the interest rate (Keynes 1936: 228). ${ }^{7}$ Here a better argument, used by Marx, is that the competition between different individual capitals leads to a general profit rate, in the case of Keynes determined by the interest rate. To summarise, Keynes argued that the marginal liquidity premium of wealth owners $(l)$ determines, in equilibrium, the interest rate $(i)$, and the latter determines the profit rate $(q)$. Thus we get $l=i=q$.

Keynes's approach has some weak points. In his model, private wealth owners have a dominant role. They determine the credit supply via their liquidity preference and also the interest rate, given a certain credit demand. The banking system does not play a role and, in contrast to the Treatise on Money (Keynes 1930), money supply is exogenously set by the central bank. Modern Keynesian approaches give the banking system a prominent role. The central bank's key policy instrument is the ability to fix the short-term refinancing rate in the money market. The banking system, together with the influence of wealth owners and credit demand, determines the long-term interest rate for credits to firms. This long-term lending rate is always above the refinancing rate in the money market. The interest rate $(i)$ then depends on the refinancing rate $\left(i_{r}\right)$, which is dictated by the central bank. An interest-rate spread of banks $\left(l_{r}\right)$ is added to the refinancing rate to determine the interest rate relevant for the firm sector, $i=i_{r}+l_{r}$. The interest-rate spread covers the costs and profits of the finance sector, as well as a risk premium. $l_{r}$ can cover the influence of wealth owners, if they have an effect on the interest rates. In most financial systems, wealth owners in this respect are relatively weak.

It is more realistic to argue that the interest rate determines the lower limit of the profit rate. In the Keynesian tradition, the degree of financialisation gives a major argument why the profit rate can be systematically higher than the interest rate. A good example of financialisation is the corporate governance system. If management searches for a compromise between the different stakeholders, then the profit rate will be moderate. If management in a shareholder management system tries to maximise profits in the short term at all costs

7. Keynes called the rate of return of investment the marginal efficiency of capital, which has nothing to do with the neoclassical marginal productivity of capital. 'There is, to begin with, the ambiguity whether we are concerned with the increment of physical product per unit of time due to the employment of one more physical unit of capital, or with the increment of value due to the employment of one more value unit of capital. The former involves difficulties as to the definition of the physical unit of capital, which I believe to be both insoluble and unnecessary' (Keynes 1936: 138). But it remains unclear why the marginal efficiency of capital should fall with increasing investment. 
and is motivated to do so by bonus payments linked to profits, the profit rate will be higher, independent of the level of the interest rate. In particular, when comparing the description of corporate governance in the US in Galbraith's (1967) description of the Great Society, ${ }^{8}$ in which management organised a compromise between different stakeholders and only got decent salaries, with the shareholder value logic advocated by Alfred Rappaport (1986) and Jack Welch, former CEO of General Electric, the paradigm shift becomes clear. If the degree of financialisation is expressed in ' $f$ ' as a percentage, the profit rate is given by $q=i_{r}+l_{r}+f$.

\section{FUNCTIONAL INCOME DISTRIBUTION IN THE KALECKIAN TRADITION}

Michał Kalecki (1965 [2009]) includes interest costs and dividend payments in overhead costs which must be covered by the prices of the sold products. This is close to Keynes's idea, especially if it is assumed that the rate of return for capital must be at least as high as the interest rate.

But Kalecki became famous for assuming that profits depend especially on the degree of monopoly. To make this point clearer, different market forms have to be distinguished. Under the assumption of pure and monopolistic competition in the medium term all costs are rolled over, entry barriers are low and as soon as high profits are earned new firms will enter and bring profits down. Only a so-called 'normal profit rate' can be earned, which is equal to the general profit rate discussed in the previous section. Pure competition means that a homogenous product is produced, whereas under monopolistic competition, product diversification takes place - for example, different restaurants offer different types of meals. In both cases, typically many firms produce and many households demand the good. In the long-run equilibrium, in both cases, profits above the general profit rate are not possible (see Chamberlin 1933; Robinson 1933). In the Keynesian approach above, implicitly pure or monopolistic competition was assumed. ${ }^{?}$

In many markets, oligopolistic structures or even monopolies exist. Oligopolies and monopolies endogenously develop when industries are characterised by economies of scale and scope. In these cases entry barriers are high because big companies in these industries can produce much more efficiently than small companies. In these markets, oligopoly or monopoly profits can be earned. Monopolies and oligopolies are confronted with a market demand curve and search for the optimal combination of sold products and prices to maximise profits. Oligopolies can create cartels and can jointly act in the same way as monopolies. Product diversification, marketing activities (such as branding), non-price competition, and the creation of intransparency are among the standard strategies of firms in such markets to increase profits. The more widespread markets with oligopoly or monopoly profits are, the higher the average profit rate in an economy will become. $^{10}$

8. The Great Society is the name of a broad programme in the 1960s under US President Lyndon B. Johnson with the main goals of ending poverty, reducing crime, abolishing inequality and improving the environment.

9. It is justified to assume, in the case of pure and monopolistic competition, the same technology in all firms since unproductive firms are crowded-out by new firms entering the market. But even if it is assumed that firms use different technologies, there is no argument about why the profit rate of the industry as a whole is not equal to the general profit rate.

10. Monopsonies can be added here, which play an important role in global value chains. 
According to Kalecki (1965), the degree of monopoly depends on several factors, which include the degree of economic concentration in an industry, the degree of non-price competition, and the bargaining power of trade unions. The first two arguments are straightforward and influence the shape of the demand curve a firm or a group of firms is confronted with. The third factor is more complicated. When costs increase and firms do not increase prices, profits will decrease. Of course, monopolies and oligopolies have the power to increase prices, but then the demand for the produced products decreases. Profit-maximising monopolies have to optimise between higher prices and lower demand. How much prices will increase depends on the demand function the firm is confronted with. Kalecki's argument with trade-union power is along these lines:

High mark-ups in existence will encourage strong trade unions to bargain for higher wages since they know that firms can 'afford' to pay them. If their demands are granted but ... [the mark-up is] not changed, prices also increase. ... But surely an industry will not like such a process making its products more and more expensive and thus less competitive with the products of other industries. To sum up, trade-union power restrains the mark-ups. (Kalecki 1971: 161; see also Kalecki 1965: 18)

Kalecki's argument stresses the importance of the corporate governance system. Under a stakeholder corporate governance system with strong trade unions and a management searching for a compromise between the different stakeholders of a firm, high revenues of firms based on market power are, to a certain extent, shared among trade unions and owners. In the case of weak trade unions, owners and management take all of the revenues as profit and obscenely high salaries.

\section{SYNTHESIS OF THE KEYNESIAN AND KALECKIAN APPROACH}

Keynes's and Kalecki's arguments complement each other. When the degree of monopoly which increases the profit rate above the general profit rate is expressed as ' $m$ ' as a percentage, the profit rate in an economy is determined by $q=i_{r}+l_{r}+f+m$. To sum up: the profit rate depends on the refinancing rate of the central bank, the spread added by the financial system, the degree of financialisation and the degree of monopoly.

To explain functional income distribution along these lines, national accounting identities can make the arguments clear. The wage sum $(W)$ in the economy is given by $W=Y-Q$ with $Y$ as income and $Q$ as profit sum. It follows that $W=Y-q \cdot P \cdot K_{r}$ with $P$ as price index and $K_{r}$ as real capital stock. Dividing both sides of the equation by $Y$ and using the definition of the capital coefficient $k=P \cdot K_{r} / Y$ provides the following definition of the wage share: $W / Y=1-q \cdot k$ or $W / Y=1-\left(i_{r}+l_{r}+f+m\right) \cdot k$. It can be seen that the wage share depends on the profit rate $q$ and the capital coefficient. The latter reflects a certain technology which is used in the economy, including the relative importance of industries with high and low capital coefficients. But it also depends on the functional income distribution as the aggregates $P \cdot K_{r}$ depend on the structure of prices and the latter on the profit rate (see Sraffa 1960). A real wage basket with all its problems does not enter the definition of the functional income distribution. Wages only play a role to the extent that trade unions can fight to get part of the extra profit of oligopolistic or monopolistic firms.

Let us look at which factors determine real wages. The capital coefficient can be written as $k=P \cdot K_{r} / P \cdot Y_{r}$ with $Y_{r}$ as real income. Dividing nominator and denominator by labour input in hours $(H)$, it follows that $k=K_{r} \cdot H / Y_{r} \cdot H$ or $k=\alpha / \pi$ with $\alpha=K_{r} / H$ as capital intensity and $\pi=Y_{r} / H$ as labour productivity. The wage share can now be written as $W / Y=1-q \cdot \alpha / \pi$. With wages per hour $(w)$, the left side of this equation can be written 
as $\left.w \cdot H / P \cdot Y_{r}=(w / P) / Y_{r} / H\right)=(w / P) / \pi$. It follows that $(w / P) / \pi=1-q \cdot \alpha / \pi$. As a final definition of real wages, it follows that $w / P=\pi-q \cdot \alpha$. This shows that real wages depend first of all on productivity, but also on the profit rate and the capital intensity.

The conclusion is that wage negotiations, which negotiate nominal wages, do not as a rule change functional income distribution and real wages. Nominal unit labour costs which increase with increasing nominal wages and decrease with increasing labour productivity are the main determinant for the price level in Keynes (1930). In a closed economy without distortions from natural resource prices, tax changes or excess demand in a situation of full capacity utilisation, etc., the development of unit labour costs determines the development of the price level. Even in the existing world, with all the different influences on the price level, there is a very close relationship between the development of nominal unit labour costs and the price level (Herr 2009). The effect stressed by Kalecki, that the strength of trade unions decides how much of extra profits workers in oligopolistic and monopolistic markets can fight for, can change functional income distribution to a certain extent, but for price-level development this effect must be considered as very small. ${ }^{11}$

Kaldor (1955), in the tradition of Keynes's Treatise on Money, argues that the share of profits in total income is a function of the ratio of investment to income, given the saving rate of wage income and profit income. This argument is based on the notion that higher net investment leads to an increase in the price level, higher profits and a higher profit share. Keynes called this demand-driven inflation 'profit inflation'. In a dynamic context, under the assumption of full capacity utilisation, this argument is correct. However, Kaldor's approach does not satisfy the conditions of the general model of functional income distribution. Keynes also did not follow such an argument and analysed profit inflation or profit deflation as phenomena of disequilibrium. The weakness of this model as a general model can be seen when net investment is assumed to be zero. Under this condition, no profit exists - a completely implausible conclusion for a general model.

\section{INTERPRETATION OF THE CHANGES IN FUNCTIONAL INCOME DISTRIBUTION}

The crises in the 1970s triggered a conservative revolution (Harvey 2005) and led to a less regulated type of capitalism. In this type of capitalism the globalisation of finance and production and weaker labour market institutions play a distinct role (Dullien et al. 2011). ${ }^{12}$ One of the resulting developments has been a falling wage share. In the tradition of post-Keynesian thinking, the falling wage share after the 1970s can be explained by the following factors.

First, increasing profit rates can be explained by financialisation and the increasing power of agents in the financial system. Gerald Epstein (2005: 3) correctly argues that 'financialization

11. If, as a general rule, nominal unit-labour-cost increases could not be rolled over, the wage share would approach one and profits would be squeezed to almost zero. For example, in the US, nominal non-farm unit labour costs increased from an index value of 17 in 1950 to 110 at the end of 2016 (Trading Economics 2017). If only 80 per cent or 90 per cent of these increases could have been rolled over, profit shares would have fallen to very low values.

12. From the 1980s onwards, personal income distribution in almost all countries increased. Changing functional income distribution is one of the important factors to explain this. Other factors are wage dispersion, wealth concentration and government redistribution (see Gallas et al. 2016). 
means the increasing of financial motives, financial markets, financial actors and financial institutions in the operation of the domestic and international economies'. Increasing profit rates were not mainly caused by higher interest rates, but because of higher pressure of agents in the financial system to increase dividend payments, increase top management salaries (which must be considered at least partly as profit) and the brutal short-term-oriented profit-maximising strategies of bigger companies especially.

Second, the degree of monopoly has increased during recent decades. Colin Crouch (2015) correctly speaks about a corporate liberalism which has developed during recent decades with an enormous concentration of economic power not regulated by political intervention. The philosophy of this type of liberalism is substantially different from the classical liberalism which wanted to prevent the power of big companies. Joseph Stiglitz (2012) stresses that the increasingly excessive rent-seeking behaviour by companies during recent decades, the increasing role of brand names for consumers, more and more sophisticated marketing strategies, artificially created non-transparency, opaque pricing systems, or political acceptance and support for very powerful - usually multinational - firms increased mark-ups for many companies and reduced the wage share. Lead firms in global value chains specialised in high-value-adding activities and used their monopsony or oligopsony power to keep profits in supplier companies at a minimum.

Third, trade union power in many countries substantially decreased. This can be measured in union density, in decreasing wage-bargaining coverage, increasing wage dispersion and hostile policies against trade unions in many countries (Herr/Ruoff 2016). Trade unions in western countries also became weaker as bigger firms substantially outsourced production to other countries (Milberg/Winkler 2013). Weaker unions are less able to fight for part of extra profits in monopolistic and oligopolistic firms.

Fourth, privatisation which after the conservative revolution in the 1970s has been widespread in many western countries also reduces the wage share. Privatisation of publicly owned firms, for example in the field of public utilities, increased the stock of capital which had to earn a profit and in this way decreased the wage share.

Fifth, Piketty (2014: 113ff) states that in western countries the capital coefficient has increased slowly since the end of World War II. Given a profit rate which is independent of the capital stock and even increased because of the arguments elaborated above, a higher capital coefficient also increases the profit share. ${ }^{13}$

There are a number of empirical investigations that stress the role of different factors contributing to the fall in the wage share over recent decades. According to these empirical studies, financialisation of the economy plays an important role as well as the weaker bargaining power of labour and globalisation processes, for example, in the field of global value chains and outsourcing (for an overview, see Detzer/Hein 2015; Dünhaupt 2017; Hein 2015; Hein et al. 2017; Stockhammer 2015). These empirical results support the theoretical approach developed above.

13. Marx (1894 [1959]: part III) assumed that an increasingly organic composition of capital (national capital stock in relation to the national wage sum) would lead to the tendency of the rate of profit to fall. 'If it is further assumed that this gradual change in the composition of capital is not confined only to individual spheres of production, but that it occurs more or less in all, or at least in the key spheres of production, so that it involves changes in the average organic composition of the total capital of a certain society, then the gradual growth of constant capital in relation to variable capital must necessarily lead to a gradual fall of the general rate of profit' (Marx 1894 [1959]: 153). In the post-Keynesian approach there is no such tendency. 


\section{REFERENCES}

Chamberlin, E. (1933): The Theory of Monopolistic Competition: A Re-orientation of the Theory of Value, Cambridge, MA: Harvard University Press.

Clark, J.B. (1899): The Distribution of Wealth: A Theory of Wages, Interest and Profits, London: Macmillan.

Crouch, C. (2015): The Knowledge Corrupters: Hidden Consequences of the Financial Takeover of Public Life, Cambridge, UK: Polity Press.

Detzer, D., Hein, E. (2015): Finance-dominated capitalism and income distribution: a Kaleckian perspective on the case of Germany, in: Italian Economic Journal, 1(2), 171-191.

Dullien, S., Herr, H., Kellermann, C. (2011): Decent Capitalism: A Blueprint for Reforming our Economies, London: Pluto Press.

Dünhaupt, P. (2017): Determinants of labour's income share in the era of financialisation, in: Cambridge Journal of Economics, 41(1), 283-306.

Epstein, G. (2005): Introduction: financialization and the world economy, in: Epstein, G. (ed.), Financialization and the World Economy, Cheltenham, UK and Northampton, MA: Edward Elgar Publishing, 3-16.

Galbraith, J.K. (1967): The New Industrial State, Boston: Houghton Mifflin.

Gallas, A., Herr, H., Hoffer, F., Scherrer, C. (eds) (2016): Combating Inequality: The Global North and South, London: Routledge.

Harcourt, G.C. (1972): Some Cambridge Controversies in the Theory of Capital, Cambridge, UK: Cambridge University Press.

Harvey, D. (2005): A Brief History of Neoliberalism, Oxford: Oxford University Press.

Hein, E. (2015): Finance-dominated capitalism and re-distribution of income: a Kaleckian perspective, in: Cambridge Journal of Economics, 39(3), 907-934.

Hein, E., Dünhaupt, P., Alfageme, A., Kulesza, M. (2017): Financialisation and distribution in the US, the UK, Spain, Germany, Sweden and France - before and after the crisis, Institute for International Political Economy Berlin Working Paper, No 85.

Herr, H. (2009): The labour market in a Keynesian economic regime: theoretical debate and empirical findings, in: Cambridge Journal of Economics, 33(5), 949-965.

Herr, H. (2014): An analytical framework for the Post-Keynesian macroeconomic paradigm, in: Izmir Review of Social Sciences, 1(2), 73-116.

Herr, H. (2018): The Communist Manifesto: what can we learn today for a country like Vietnam?, Institute for International Political Economy Berlin Working Paper, No 98.

Herr, H., Ruoff, B. (2016): Labour and financial markets as drivers of inequality, in: Gallas, A., Herr, H., Hoffer, F., Scherrer, C. (eds), Combating Inequality: The Global North and South, London: Routledge, 61-79.

Kaldor, N. (1955): Alternative theories of distribution, in: The Review of Economic Studies, 23(2), 83-100.

Kalecki, M. (1965 [2009]): Theory of Economic Dynamics, 2nd edn, New York: Augustus Kelley.

Kalecki, M. (1971): Selected Essays on the Dynamics of the Capitalist Economy, Cambridge, UK: Cambridge University Press.

Keynes, J.M. (1930): A Treatise on Money, Cambridge, UK: Cambridge University Press.

Keynes, J.M. (1936): The General Theory of Employment, Interest and Money, Cambridge, UK: Cambridge University Press.

Keynes, J.M. (1937a): The general theory of employment, in: Quarterly Journal of Economics, 51(2), 209-223.

Keynes, J.M. (1937b): Alternative theories of the rate of interest, in: Economic Journal, 47(186), $241-252$.

Lakatos, I. (1978): The Methodology of Scientific Research Programmes, Philosophical Papers Volume 1, Cambridge, UK: Cambridge University Press.

Lazzarini, A. (2011): Revisiting the Cambridge Capital Theory Controversies: A Historical and Analytical Study, Pavia: Pavia University Press.

Marx, K. (1867 [1887]): Capital: A Critique of Political Economy, Volume I, The Process of Production of Capital, Moscow: Progress Publishers (first English edition 1887). 
Marx, K. (1894 [1959]): Capital: A Critique of Political Economy, Volume IIII, The Process of Capitalist Production as a Whole, Moscow: Institute of Marxism-Leninism (first publication edited by F. Engels; English publication 1959).

Marx, K., Engels, F. (1848 [2006]): Communist Manifesto, published online by Socialist Labor Party of America, URL: http://www.slp.org/pdf/marx/comm_manifesto.pdf (English publication 2006).

Milberg, W., Winkler, D. (2013): Outsourcing Economics: Global Value Chains in Capitalist Development, Cambridge, UK: Cambridge University Press.

OECD (2012): OECD Employment Outlook, Paris: OECD Publications.

Piketty, T. (2014): Capital in the Twenty-First Century, Cambridge, MA: Belknap Press.

Polanyi, K. (1944): The Great Transformation, New York: Farrar \& Rinehart.

Rappaport, A. (1986): Creating Shareholder Value, New York: Free Press.

Riese, H. (2002): Zur Mikrofundierung der Verteilungstheorie - Einsicht in eine unvollendete Geschichte, in: Menkhoff, L., Sell, F.L. (eds), Zur Theorie, Empirie und Politik der Einkommensverteilung, Festschrift für Gerold Blümle, Berlin: Springer, 37-57.

Robinson, J. (1933): The Economics of Imperfect Competition, London: Macmillan.

Samuelson, P.A. (1966): A summing up, in: Quarterly Journal of Economics, 80(4), 568-583.

Schumpeter, J.A. (1942 [2014]): Capitalism, Socialism and Democracy, 2nd edn, Floyd, VA: Impact Books.

Smith, A. (1776 [2007]): An Inquiry into the Nature and Causes of the Wealth of Nations, Lausanne: MetaLibri.

Sraffa, P. (1960): Production of Commodities by Means of Commodities: Prelude to a Critique of Economic Theory, Cambridge, UK: Cambridge University Press.

Stiglitz, J. (2012): The Price of Inequality, New York: W.W. Norton.

Stockhammer, E. (2015): Determinants of the wage share: a panel analysis of advanced and developing countries, in: British Journal of Industrial Relations, 55(1), 3-33.

Trading Economics (2017): URL: https://tradingeconomics.com. 